\title{
Non-native plant species in alder-dominated forests in Slovakia: what does the regional- and the local-scale approach bring?
}

\author{
Michal Slezák ${ }^{1 *}$, Štefánia Farkašovská ${ }^{2}$, Richard Hrivnák ${ }^{3}$ \\ ${ }^{1}$ Institute of Forest Ecology, Slovak Academy of Sciences, L. Štúra 2, SK-960 53 Zvolen, Slovakia \\ ${ }^{2}$ Školská 10, SK-053 21 Markušovce, Slovakia \\ ${ }^{3}$ Institute of Botany, Plant Science and Biodiversity Center, Slovak Academy of Sciences, \\ Dúbravská cesta 9, SK-845 23 Bratislava, Slovakia
}

\begin{abstract}
SLEZÁk, M., FARKašovská, Š., HrivnáK, R., 2020. Non-native plant species in alder-dominated forests in Slovakia: what does the regional- and the local-scale approach bring? Folia Oecologica, 47 (2): 100-108.

European riparian forests are in general susceptible to plant invasions compared to other natural forest habitats. Their descriptive vegetation overviews with phytosociological affiliation contain detail insight into species composition patterns at various geographical scales, but quantitative assessment of the relationship between non-native plant richness and measured environmental variables is still scarce. We used two vegetation datasets of alder-dominated forests to analyse plant invasion patterns in the Pannonian and the Carpathian region of Slovakia. A large dataset of 918 vegetation plots was used at the regional scale, whereas 40 vegetation plots completed by ecological (mainly soil, climatic) predictors were used at the local scale in order to determine how they shape non-native species richness. We found significant differences $(P<0.05)$ between the Pannonian and the Carpathian region in the number of non-native vascular plants at both scales, with altitude being the most important predictor. Generalized Linear Models accounted for 56.6\% and 59.6\% of alien species richness data in the Pannonian and Carpathian region, respectively. Alien richness was affected by altitude and soil $\mathrm{pH}$ in the Pannonian region, but only by altitude in the Carpathian region.
\end{abstract}

\section{Keywords}

alien vascular plants, altitude, floodplain forests, invasibility, lowland and mountainous regions, Slovakia

\section{Introduction}

Plant invasions are considered to be one of the major threats to plant biodiversity, causing its decline and homogenization (Š́ıíKovÁ et al., 2019). Although individual habitats showed different susceptibility to plant invasions (PYšEK et al., 2012; MedvEcká et al., 2018), recent biodiversity and comparative studies have shown increasing numbers of non-native species in various natural and seminatural habitats across temperate regions (e.g. BERG et al., 2016). This trend was also observed in floodplain forests (e.g. Petrášová et al., 2013), which were identified as one of the most invaded forest habitats in Europe (WAGNER et al., 2017).

Floodplain forests represent a dynamic interface between freshwater and terrestrial ecosystems with high intensity of propagule transfer and degree of disturbances. They usually grow along rivers and streams from lowlands to montane regions, including spring areas. Their herb-layer structure consists of species with different ecological niches and origins, including alien species. Vegetation structure is commonly built up by hygrophilous plants

*Corresponding author: 
accompanied by forest mesophilous species (DoudA et al., 2016). In Slovakia, the last decade was a period of phytosociological research of floodplain forests, which resulted in national vegetation overviews (PETRÁŠOvá and JAROLÍMEK, 2012; SLEZÁK et al., 2014). Although several local studies explored the effects of various environmental predictors on their floristic and diversity variation (e.g. SLEZÁK et al., 2017; HrivnáK et al., 2020), studies focusing on richness of non-native plants in relation to measured ecological factors are still lacking.

Previous research devoted to determine causal factors of alien richness using large datasets highlighted the role of altitude (MedvecKá et al., 2014). However, it may interact with productivity or nutrient availability to govern the number of aliens, primarily neophytes (species introduced after year 1500; Petrášová et al., 2013). Slovakia represents a good model region for such complex study (see e.g. Medvecká et al., 2014) because its territory has well-developed fluvial network and contains two climatic and biogeographical regions. While a colder and more humid Carpathian climate affects mainly the northern part of the country, longer warmer and dried periods are typical for the southern Pannonian region. The Carpathian region is rather mountainous compared to the Pannonian region with prevalence of lowlands and uplands. Although they differ in climate and dominant landscape structure, floodplain forests are well-documented by vegetation relevés in both.

We aimed to determine potential regional differences between the Pannonian and the Carpathian region in species richness of non-native vascular plants using large vegetation datasets of alder-dominated floodplain forests from Slovakia. At the local scale, vegetation records were completed by environmental data in order to determine how these predictors affect plant species diversity of aliens. We expect differences in the number of non-native vascular plants in alder floodplain forests between regions irrespective of study scale (regional vs. local) and importance of altitude (or climate-induced variables) which could act together with some soil properties to control alien richness at the local scale.

\section{Materials and methods}

We studied vegetation of alder-dominated forests comprising riparian alder forests (phytosociological alliance Alnion incanae Pawłowski et al. 1928) and alder carrs (Alnion glutinosae Malcuit 1929) with a cover of tree layer of Alnus glutinosa and $A$. incana higher than 50\% (SLEZÁK et al., 2014) at two geographical scales (regional and local). Only natural and semi-natural stands were recorded. Regional approach covered whole Slovakia, whereas the local one included central Slovakia (Fig. 1). Both scales contained the Pannonian and Western Carpathian (further only Carpathians) bioregions (FUTÁK, 1984). Altogether 918 vegetation relevés (285 in the Pannonian and 622 in the Carpathian bioregion) with plot size of 100-400 $\mathrm{m}^{2}$ were acquired from the Slovak vegetation database (https://www.givd.info/ID/EU-SK-001) in order to anal- yse species richness pattern of non-native vascular plants at the regional scale. Forty vegetation plots (the Pannonian bioregion - 20 and the Carpathian bioregion - 20) with a uniform size of $400 \mathrm{~m}^{2}$ were sampled by the authors at the local scale in vegetation seasons of 2009-2015. They were recorded in accordance with the traditional ZürichMontpellier approach, stored in the Turboveg database (Hennekens and Schaminée, 2001) and exported into the Juice programme (TICHÝ, 2002). Alien vascular plants including archaeophytes and neophytes followed the checklist of MEDVECKÁ et al. (2012) and the nomenclature of vascular plants the checklist of MARHOLD and HINDÁK (1998).

We recorded or calculated 15 environmental variables for each vegetation plot at the local scale (Table 1). They comprised mainly soil, climatic and hydrological factors, which were formerly found to be significant in relation to vegetation diversity of floodplain forests (e.g. DoudA et al., 2012; HrivnáK et al., 2015, 2020; Pielech, 2015; SLEZÁK et al., 2017). Geographical coordinates (latitude, longitude) and altitude as well as aspect were measured by GPSmap $60 \mathrm{CSx}$. Soil samples were taken from three places considering microrelief and moisture heterogeneity from the topsoil mineral horizon (litter layer removed) at a depth of $0-10 \mathrm{~cm}$, where most of the vascular plants is rooted (cf. SLEZÁk et al., 2017). These three samples were pooled to single sample per plot in order to reduce soil heterogeneity. They were air-dried at a laboratory temperature, crushed and passed through a $2 \mathrm{~mm}$ sieve. Total carbon (Ctot) and nitrogen (Ntot) contents were determined using an NCS-FLASH 1112 analyzer (CE Instruments, $\mathrm{UK}$ ) and used to calculate the $\mathrm{C} / \mathrm{N}$ ratio. Soil $\mathrm{pH}$ and conductivity were measured in distilled water (soil/water ratio of 1/5) using a $\mathrm{pH}$ (WTW Inolab $\mathrm{pH} 720$ ) and conductivity (WTW Inolab Cond 720) meter, respectively. Plantavailable phosphorus (P) was extracted in the Mehlich II solution and measured by spectrophotometry (AES-ICP). Cations of calcium $(\mathrm{Ca})$, magnesium $(\mathrm{Mg})$, potassium $(\mathrm{K})$, sodium $(\mathrm{Na})$ and iron $(\mathrm{Fe})$ were extracted in the Mehlich III solution and determined using an atomic absorption spectro-photometer (SensAA, GBC; UK). Climatic data were provided by the Slovak Hydrometeorological Institute (Bratislava, Slovakia). Based on geographical coordinates, mean annual temperature and mean annual precipitation (records from the period 1961-1990) were derived from raster values computed in the GRASS GIS environment (NETELER et al., 2012). Stream power index (SPI) was derived from a digital elevation model (DEM; Geodetic and Cartographic Institute, Bratislava, Slovakia) using GRASS GIS (for details see SLEZÁK et al., 2017).

Spearman rank correlations $\left(r_{s}\right)$ were used to reduce multicollinearity among environmental variables (Appendix 1). From two or more collinear predictors $\left(r_{s} \geq 0.7\right)$, only one predictor was retained prior to further analyses. Finally, we used altogether 8 variables (altitude, soil reaction and conductivity, contents of $\mathrm{K}, \mathrm{Fe}$ and $\mathrm{P}, \mathrm{C} / \mathrm{N}$ ratio and SPI) as explanatory variables in Generalized Linear Model (GLM) with Poisson distribution of errors and logarithmic link function. The minimal adequate model for alien richness pattern followed backward selection based 


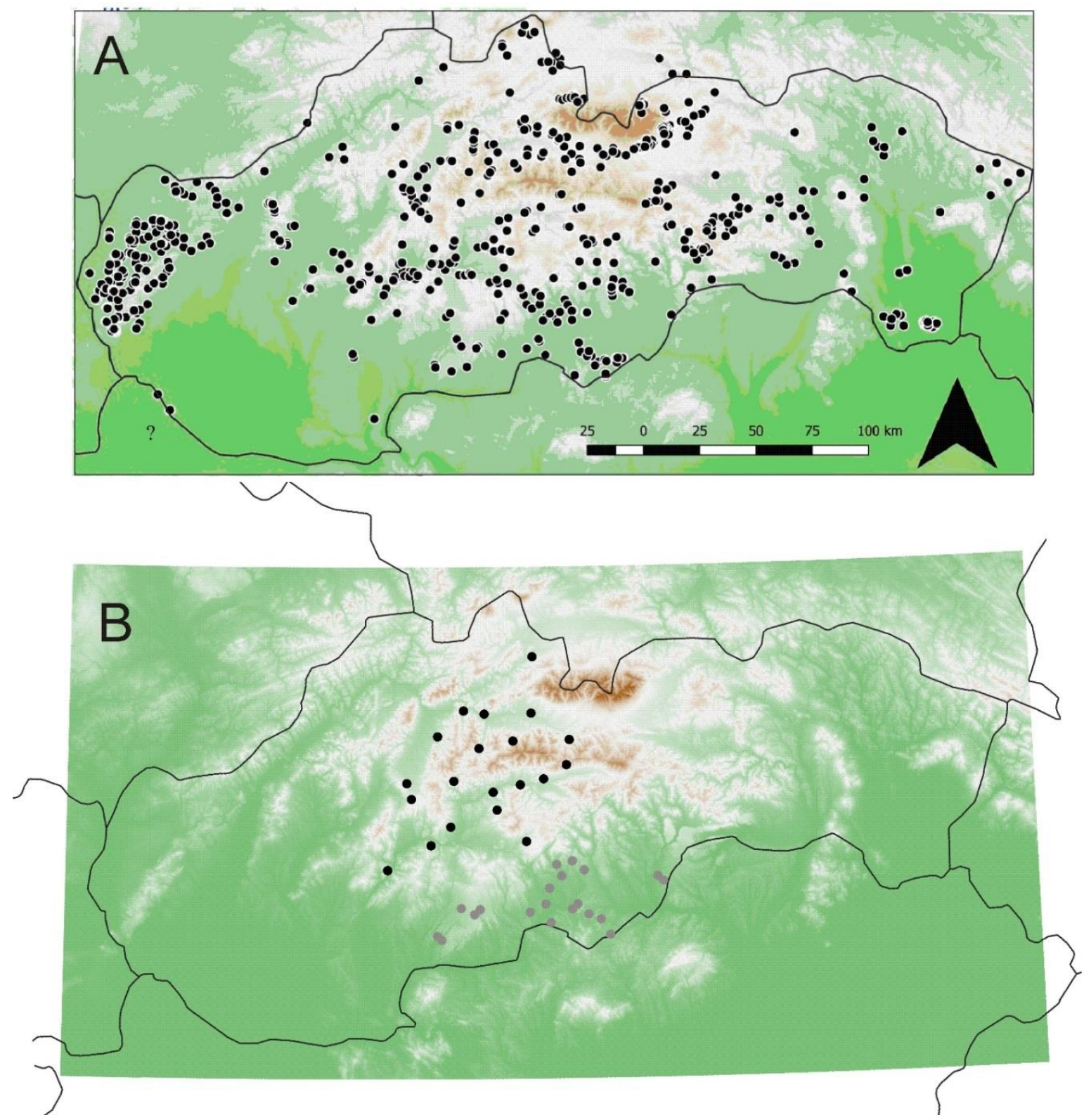

Fig. 1. Map of vegetation plots in the regional- (A, Slovakia, $\mathrm{n}=918$ samples) and local-scale study (B, central Slovakia, $\mathrm{n}=40$ samples; grey circles - Pannonian region, black circles - Carpathian region).

on Akaike information criterion. The goodness-of-fit of the model corresponded to percentage of explained deviance adjusted by the number of observations and model parameters (GUISAN and ZimMERMANN, 2000). Differences between bioregions in environmental variables at the local scale as well as alien plant richness at the regional and local scales were determined using Mann-Whitney U-test. All analyses were conducted in R (ver. 3.0.2, R Core Team 2013).

\section{Results}

The species richness of non-native plants within alderdominated forests in Slovakia (regional scale) comprised
58 vascular plants. It was built up by 29 archaeophytes and 29 neophytes (Appendix 2). Higher alien richness was found in the Pannonian compared to the Carpathian bioregion, with mean number of 1 species and 0.6 species per plot, respectively $(P<0.001)$. Altogether 21 alien plant species were found at the local scale, but the difference was not statistically significant $(P>0.05$; Table 1$)$. We identified 15 species in the Pannonian and 13 species in the Carpathian bioregion, with neophytes Bidens frondosa and Impatiens parviflora being the most frequent aliens recorded in 16 vegetation plots. The other most frequent species in the Pannonian subset were Aethusa cynapium, Arctium tomentosum and Stenactis annua - all with three records, whereas in the Carpathian subset only the neophyte species Ribes rubrum showed four records and the 


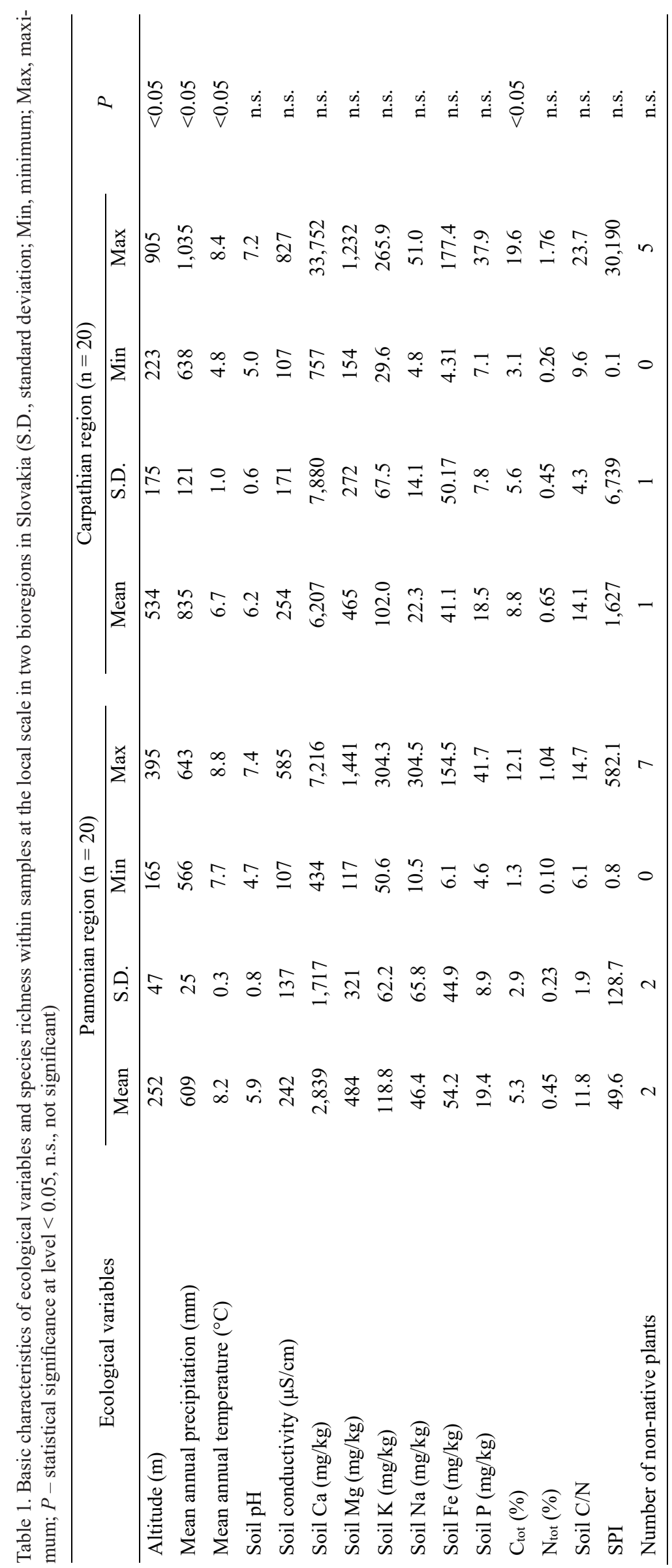


remaining species were documented only on less than three plots.

Vegetation plots of alder-dominated forests in the Pannonian and Carpathian region showed significant differences $(P<0.05)$ in altitude and related climatic characteristics (mean annual temperature and precipitation). Although the analysed forest stands varied from nutrientpoor to nutrient-rich stands, soil chemical properties did not significantly differ except for carbon content (Table 1). The results of GLM showed significant effect of two ecological variables (altitude and soil $\mathrm{pH}$ ) on species richness of non-native plants (Table 2). Altitude had significant effects in both regions, but its explanatory power was higher in the case of the Carpathian than the Pannonian region. Numbers of alien species decreased with increasing altitude in both regions (Fig. 2). In the Pannonian region, alien plant richness was also positively driven by soil $\mathrm{pH}$ gradient, with the highest values on plots with neutral to slightly alkaline soils (Fig. 2). The explained variation of alien species richness data was $56.6 \%$ and $59.6 \%$ in the Pannonian and the Carpathian region, respectively (Table 2).

\section{Discussion}

Riparian floodplain forests frequently show a high level of plant invasions among natural forest habitats (CHYTRÝ et al., 2009a; Petrášová et al., 2013; Medvecká et al., 2014; WAGNER et al., 2017). They represent various types of deciduous forests associated with flooded riparian and waterlogged non-riparian sites, both in the lowlands and uplands with a dominance of alders (Alnus glutinosa, A. incana), ashes (Fraxinus angustifolia subsp. danubialis, $F$. excelsior), elms (Ulmus laevis, U. minor), poplars (Populus alba, P. nigra), oaks (Quercus pedunculiflora, Q. robur) and willows (Salix spp.; DoudA et al., 2016). These forest vegetation types strongly differ in their ecological affinities (e.g. position along altitudinal or productivity gradient), susceptibility to plant invasions and consequently, they vary in the frequency of aliens (WAGNER et al., 2017). Our results coincide with previous findings that alder-dominated forests are less invaded by alien plants compared to other broadleaved deciduous forests on hygrophilous sites (MEDVECKá et al., 2018). If total alien plant species pool in Slovakia is taken into account (MEDVECKÁ et al., 2012), we found only $6.3 \%$ and $2.3 \%$ of alien plants at the regional and local scale, respectively. This could be attributed to overall number and composition of alien species pool, which seems to be controlled mainly by vascular plants of anthropogenic or ruderal sites. A comparative analysis performed across woodlands and treeless habitats demonstrated that just human-induced habitats (e.g. herb stands of annuals and perennials, arable land, trampled sites) belong to the most invaded globally (MEDvECKÁ et al., 2014).

The most common non-native species in hygrophilous alder-dominated forests (local subset) were Impatiens parviflora and Bidens frondosa. While the last one prefers moist and eutrophic sites, I. parviflora can also thrive in other woodlands with various moisture and nutrient conditions (JARČUŠKA et al., 2016). Success of this species is usually attributed to its wide ecological niche (ČUDA et al., 2014).

Altitude was found to be the crucial factor affecting alien plant richness in both regions, but higher number of aliens was recorded in the lowland Pannonian region compared to the mountainous Carpathian region. Alien richness-altitude relationship showed monotonically decreasing trend along altitudinal gradient. The decline of alien richness towards higher altitudes is in general wellestablished pattern (e.g. PYŠEK et al., 2002; CHYTRÝ et al., 2009b; Medvecká et al., 2014). Higher invasion level in lowland areas most likely results from a high propagule pressure of aliens and a higher disturbance level as a consequence of human activities as well as favourable climatic conditions for alien plant species in lowlands comparing with mountainous regions. In more detail, long-term human impact and landscape utilization in time and space (e.g. intensity of agricultural activities, industry, disturbances or settlement) are more pronounced in lowlands than mountainous regions. In addition, a decrease of neophyte proportion with distance from the main stream detected within floodplain forests in Slovenia can be explained by the importance of their effective propagation ensured by the flow of the main stream (Košir et al., 2013). Previous biodiversity research also showed importance of human-induced disturbances for synanthropic plants of forests and their species richness (e.g. GUIRADO et al., 2007). Non-native species richness was associated with soil reaction as well, although its significant effect was recognized only in the Pannonian region. It has been shown in various types of floodplain forests that soil $\mathrm{pH}$ determines variation of total understory species richness (DoudA et al., 2012; SLEZÁK et al., 2017). Positive linear relationship found in our study is consistent with the theory that nutrient-rich and productive sites with a high soil

Table 2. Generalized linear model (GLM) of alien plant species richness in alder-dominated forests at the local scale

\begin{tabular}{|c|c|c|c|c|c|}
\hline & $\begin{array}{c}\text { Standardized } \\
\text { coefficients }\end{array}$ & $\begin{array}{c}\text { Standard } \\
\text { errors }\end{array}$ & $Z$-value & $\begin{array}{c}\text { Significance } \\
\text { level }(P)\end{array}$ & $\begin{array}{l}\text { Explained } \\
\text { variability }\end{array}$ \\
\hline \multicolumn{6}{|c|}{ Pannonian region $(\mathrm{n}=20)$} \\
\hline Altitude & -0.012 & 0.005 & -2.371 & $=0.018$ & $27.6 \%$ \\
\hline Soil pH & 0.668 & 0.218 & 3.057 & $=0.002$ & $28.9 \%$ \\
\hline \multicolumn{6}{|c|}{ Carpathian region $(n=20)$} \\
\hline Altitude & -0.005 & 0.001 & -4.035 & $<0.001$ & $59.6 \%$ \\
\hline
\end{tabular}




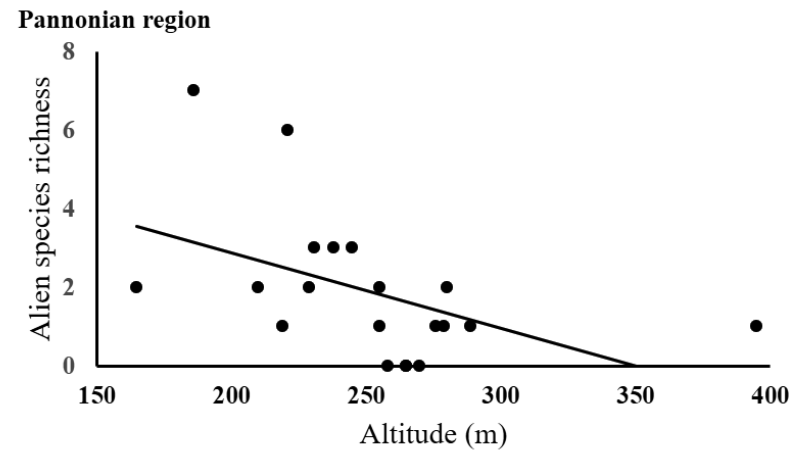

Pannonian region
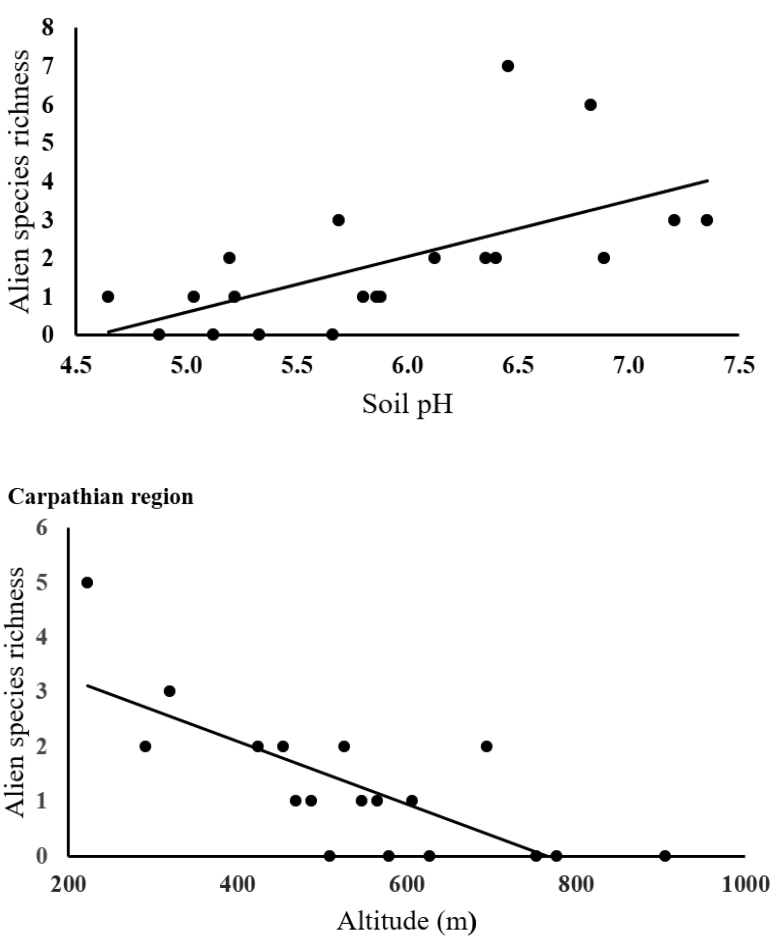

Fig. 2. Visualization of the relationships between alien plant species richness and statistically significant ecological variables following the results of GLM (Table 2).

$\mathrm{pH}$ are prone to plant invasions and promote occurrence of non-native plant species (Petrášoví et al., 2013; WAGNER et al., 2017). At the same time, acidic soils with low pH values act as important eco-physiological constraints for many vascular plants, including alien plants (CHYTRÝ et al., 2008).

\section{Conclusions}

The results of this study showed invasibility of alder-dominated forests by non-native vascular plants in Slovakia. Although floodplain forests belong to the most invaded natural woodlands, studied riparian alder forests seem to be relatively less influenced from this group. The lowland Pannonian region harboured higher number of alien plants than the montane Carpathian region. Our study further demonstrates the role of altitude and soil $\mathrm{pH}$ in shaping alien species richness.

\section{Acknowledgements}

We thank D. Gömöry for language improvement and both anonymous reviewers for their constructive comments. The research was supported by the Science Grant Agency of the Ministry of Education of the Slovak Republic and the Slovak Academy of Sciences (VEGA 2/0016/19).

\section{References}

Berg, C., Drescher, A., Wagner, V., EssL, F., 2016. Temporal trends in the invasions of Austrian woodlands by alien trees. Preslia, 88: 185-200.

Chytrý, M., Jarošíi, V., Pyšek, P., HáJek, O., Knollová, I., Tichý, L., DANiHelKa, J., 2008. Separating habitat invasibility by alien plants from the actual level of invasion. Ecology, 89: 1541-1553.

ChytrÝ, M., Pyšek, P., Wild, J., Pino, J., Maskell, L.C., VILÀ, M., 2009a. European map of alien plant invasions, based on the quantitative assessment across habitats. $D i$ versity and Distributions, 15: 98-107.

Chytrý, M., Wild, J., Pyšek, P., Tichý, L., Danihelka, J., KNOLLOvá, I., 2009b. Maps of the level of invasion of the Czech Republic by alien plants. Preslia, 81: 187-207.

ČudA, J., Skálová, H., JANOvskÝ, Z., PYšek, P., 2014. Habitat requirements, short-term population dynamics and coexistence of native and invasive Impatiens species: a field study. Biological Invasions, 16: 177-190.

Douda, J., Boublík, K., Slezák, M., Biurrun, I., Nociar, J., Havrdová, A., Doudová, J., Aćić, S., Brisse, H., Brunet, J., Chytrú, M., Claessens, H., Csiky, J., Didukh, Y., Dimopoulos, P., Dullinger, S., FitzPatrick, Ú., Guisan, A., Horchler, P.J., Hrivnák, R., Jandt, U., KącKi, Z., Kevey, B., Landucci, F., Lecomte, H., Lenoir, J., PaAl, J., Paternoster, D., Pauli, H., Pielech, R., Rodwell, J.S., Roelandt, B., Svenning, J.-C., Šibík, J., ŠIlc, U., ŠKvore, Ž., Tsiripidis, I., Tzonev, R.T., Wohlgemuth, T., ZimmermanN, N.E., 2016. Vegetation classification and biogeography of European floodplain forests and alder carrs. Applied Vegetation Science, 19: 147-163.

Douda, J., Doudová-Kochánková, J., Boublík, K., DraŠnAROvÁ, A., 2012. Plant species coexistence at local scale in temperate swamp forest: test of habitat heterogeneity hypothesis. Oecologia, 169: 523-534.

FutÁk, J., 1984. Fytogeografické členenie Slovenska [Phytogeographical differentiation of Slovakia]. In BERTOvá, L. (ed). Flóra Slovenska IV/1. Bratislava: Veda, 1984, p. 418-419.

Guirado, M., PinO, J., Rodì, F., 2007. Comparing the role of site disturbance and landscape properties on understory species richness in fragmented periurban Mediterranean forests. Landscape Ecology, 22: 117-129.

Guisan, A., Zimmermann, N.E., 2000. Predictive habitat distribution models in ecology. Ecological Modelling, 135: $147-186$. 
HenNekens, S.M., Schaminée, J.H.J., 2001. TURBOVEG, a comprehensive data base management system for vegetation data. Journal of Vegetation Science, 12: 589-591.

HrivnÁK, R., SLezÁK, M., JarčUŠKa, B., JarolímeK, I., KoCHJAROvá, J., 2015. Native and alien plant species richness response to soil nitrogen and phosphorus in temperate floodplain and swamp forests. Forests, 6: 3501-3513.

Hrivnák, R., Svitok, M., Kochjarová, J., Jarolímek, I., Machava, J., Senko, D., Slezák, M., 2020. Drivers of plant species composition in alder-dominated forests with contrasting connectivity. Wetlands Ecology and Management, 28: 137-150.

JarČuŠKa, B., Slezák, M., Hrivnák, R., Senko, D., 2016. Invasibility of alien Impatiens parviflora in temperate forest understories. Flora, 224: 14-23.

KošIr, P., ČArni, A., MarinšEK, A., ŠILC, U., 2013. Floodplain forest communities along the Mura River (NE Slovenia). Acta Botanica Croatica, 71: 71-95.

Marhold, K., HindÁK, F. (eds), 1998. Checklist of non-vascular and vascular plants of Slovakia. Bratislava: Veda. $688 \mathrm{p}$.

MedveckÁ, J., JarolímeK, I., HegedüŠová, K., ŠKodovÁ, I., Bazalová, D., Botková, K., Šibíková, M., 2018. Forest habitat invasions - Who with whom, where and why. Forest Ecology and Management, 409: 468-478.

Medvecká, J., Kliment, J., Májeková, J., Halada, L., ZALIBERová, M., GoJdičová, E., Feráková, V., JarolímeK, I., 2012. Inventory of the alien flora of Slovakia. Preslia, 84: 257-309.

MedveckÁ, J., Jarolímek, I., Senko, D., Svitok, M., 2014. Fifty years of plant invasion dynamics in Slovakia along a $2,500 \mathrm{~m}$ altitudinal gradient. Biological Invasions, 16 : $1627-1638$

Neteler, M., Bowman, M.H., Landa, M., Metz, M., 2012. GRASS GIS: A multi-purpose open source GIS. Environmental Modelling and Software, 31: 124-130.

Petrášová, M., JAROLÍMEK, I., 2012. Hardwood floodplain forests in Slovakia: syntaxonomical revision. Biologia, 67: 889-908.

Petrášová, M., Jarolímek, I., MedveckÁ, J., 2013. Neophytes in Pannonian hardwood floodplain forests - His- tory, present situation and trends. Forest Ecology and Management, 308: 31-39.

Pielech, R., 2015. Formalised classification and environmental controls of riparian forest communities in the Sudets (SW Poland). Tuexenia, 35: 155-176.

PyŠEK, P., ChYtrÝ, M., Pergl, J., SÁDlo, J., Wild, J., 2012. Plant invasions in the Czech Republic: current state, introduction dynamics, invasive species and invaded habitats. Preslia, 84: 575-629.

PYŠEK, P., JAROšíK, V., KučERA, T., 2002. Patterns of invasion in temperate nature reserves. Biological Conservation, 104: 13-24.

SLEZÁK, M., HrivnÁK, R., Machava, J., 2017. Environmental controls of plant species richness and species composition in black alder floodplain forests of central Slovakia. Tuexenia, 37: 79-94.

SlezÁk, M., Hrivnák, R., Petrášová, A., 2014. Numerical classification of alder carr and riparian forests in Slovakia. Phytocoenologia, 44: 283-308.

ŠibíkovÁ, M., JARolímeK, I., HegedüŠová, K., MáJeKová, J., Mikulová, K., Slabejová, D., ŠKodová, I., Zaliberová, M., Medvecké, J., 2019. Effect of planting alien Robinia pseudoacacia trees on homogenization of Central European forest vegetation. Science of the Total Environment, 687: 1164-1175.

TICHÝ, L., 2002. JUICE, software for vegetation classification. Journal of Vegetation Science, 13: 451-453.

Wagner, V., Chytrर́, M., Jiménez-Alfaro, B., Pergl, J., Hennekens, S., Biurrun, I., Knollová, I., Berg, C., VasSILEv, K., Rodwell, J.S., ŠKvorc, Ž., JANDT, U., Ewald, J., Jansen, F., Tsiripidis, I., Botta-Dukát, Z., Casella, L., Attorre, F., Rašomavičius, V., Ćusterevska, R., SChaminée, J.H.J., Brunet, J., Lenoir, J., Svenning, J.C., Kącki, Z., Petrášová-Šıbíková, M., ŠIllc, U., GaRCía-Mijangos, I., Campos, J.A., FernándeZ-González, F., Wohlgemuth, T., Onyshchenko, V., PyšEK, P., 2017. Alien plant invasions in European woodlands. Diversity and Distributions, 23: 969-981.

Received May 1, 2020 Accepted October 8, 2020 


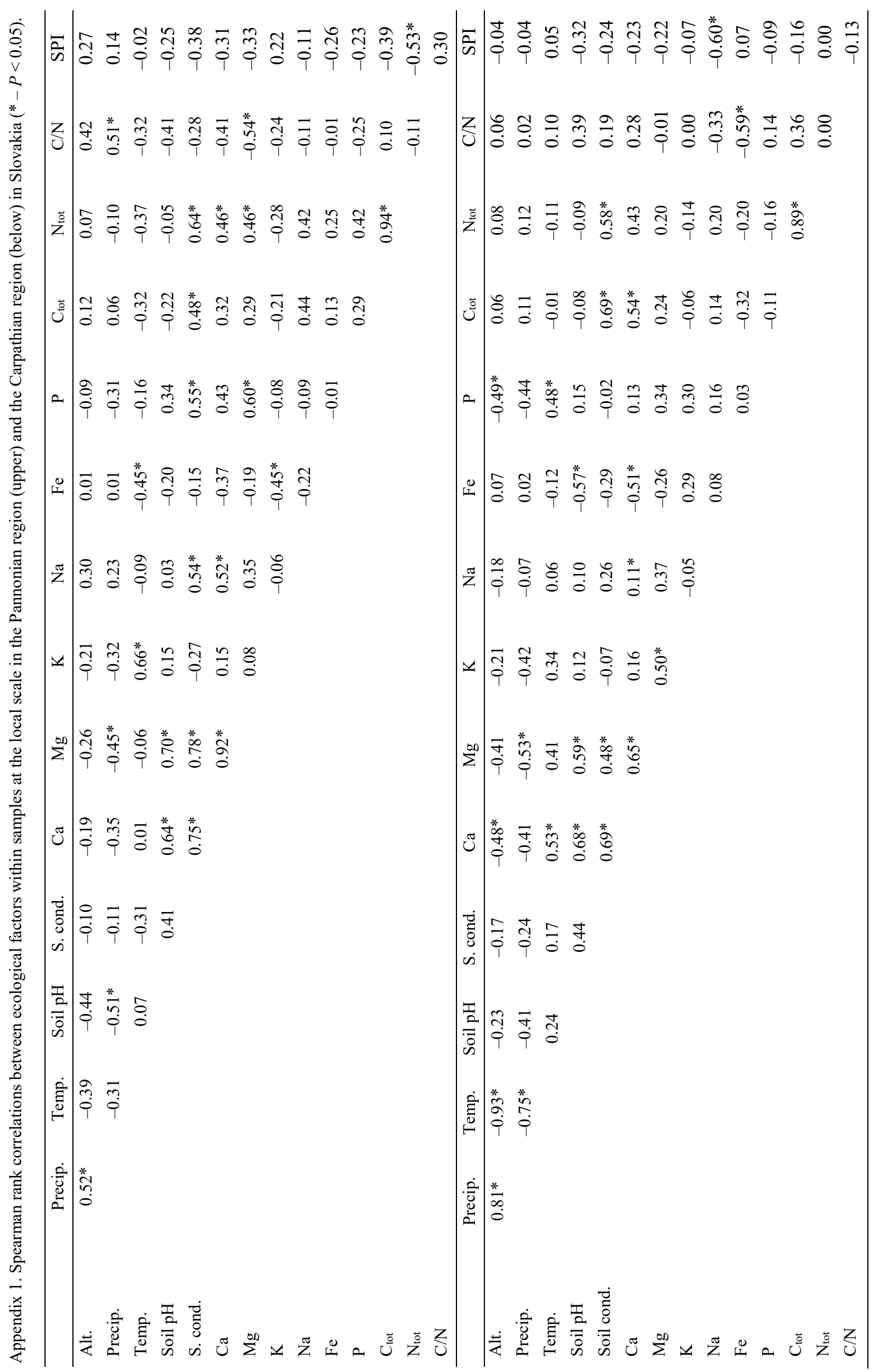


Appendix 2. List of alien vascular plants found in regional scale (arch - archaeophytes, neo - neophytes).

Acorus calamus (neo), Aesculus hippocastanum (neo), Aethusa cynapium (arch), Ailanthus altissima (neo), Anthriscus cerefolium (arch), Arctium lappa (arch), Arctium minus (arch), Arctium tomentosum (arch), Armoracia rusticana (arch), Aster novi-belgii (neo), Bidens frondosa (neo), Bromus sterilis (arch), Cerasus vulgaris (arch), Conium maculatum (arch), Convolvulus arvensis (arch), Conyza canadensis (neo), Dalanum angustifolium (arch), Daucuc carota (arch), Echinocystis lobata (neo), Epilobium ciliatum (neo), Erechtites hieracifolius (neo), Fallopia convolvulus (arch), Fallopia japonica (neo), Fraxinus pennsylvanica (neo), Galinsoga parviflora (neo), Galinsoga urticifolia (neo), Chelidonium majus (arch), Chenopodium polyspermum (arch), Impatiens glandulifera (neo), Impatiens parviflora (neo), Juglans nigra (neo), Juglans regia (arch), Juncus tenuis (neo), Lactuca serriola (arch), Lamium album (arch), Lamium purpureum (arch), Malva sylvestris (arch), Mentha ' piperita (neo), Negundo aceroides (neo), Padus serotina (neo), Parietaria officinalis (arch), Phytolacca americana (neo), Populus ' canadensis (neo), Pyrus communis (arch), Ribes rubrum (neo), Robinia pseudoacacia (neo), Rudbeckia laciniata (neo), Silene latifolia (arch), Solanum nigrum (arch), Solidago canadensis (neo), Solidago gigantea (neo), Sonchus arvensis ( $\operatorname{arch})$, Sonchus asper ( $\operatorname{arch})$, Sonchus oleraceus ( $\operatorname{arch})$, Stenactis annua (neo), Tithymalus helioscopia ( $\operatorname{arch})$, Tripleurospermum perforatum $(\operatorname{arch})$, Urtica urens ( $\operatorname{arch})$, Xanthoxalis stricta (neo). 